\title{
Chromosome Segregation
}

National Cancer Institute

\section{Source}

National Cancer Institute. Chromosome Segregation. NCI Thesaurus. Code C28547.

The separation of chromosomes into daughter cells during cell division. (GO) 